\title{
Listening Twice to Bernhard Gander's "Peter Parker"
}

Axel Petri-Preis

Artists

Joonas Ahonen, piano \& Bernhard Gander, composer

Concept and moderation

Axel Petri-Preis

Programme

Bernhard Gander: "Peter Parker" (2004)

The concept of the "2xHören" [listening twice] format is as simple as it is brilliant: the audience listens to a piece of music twice, at the beginning and at the end of a concert. In between, a moderator provides the audience with insights, for example by talking to the artists, zooming in on parts of the piece, conducting listening experiments, or giving information about its sociocultural context.

"2xhören" was developed by the Körber Stiftung Hamburg. ${ }^{1}$ It started in 2006 with Markus Fein as moderator and soon found its way into the Musikvermittlung repertoire of concert halls (e.g. Konzerthaus Berlin). ${ }^{2}$ The idea of listening to an artwork twice isn't entirely new. The pianist Hans von Bülow used to perform Ludwig van Beethoven's monumental "Sonate for Hammerklavier" twice and thus enabled the work, which was extraordinary for the ears of the time, to find a place in the concert repertoire. Willem Mengelberg played

For video recordings see https://www.koerber-stiftung.de/veranstaltungsuebersicht/re ihen/2-x-hoeren-1.

2 For more information about the history and the educational approach, see Musil (2013). 
Gustav Mahler's "Symphony No. 4" twice in a 1903 concert, first conducting it himself and then with Mahler on the podium. Mahler wrote to his wife that this was a great idea to make the audience comfortable with his piece. Lastly, the concept of playing a piece repeatedly in order to allow for more informed listening also played an important role in Arnold Schönberg's "Verein für musikalische Privataufführungen".

What can be seen from these historical examples is that the intention behind listening to a piece twice in the course of a concert was to support the audience in getting accustomed to a new piece of music and in listening to it differently the second time. This is exactly the idea behind the " $2 x H$ Hören" format, which seeks to lead the audience to deeper and more informed listening and facilitate aesthetic experiences.

In the course of our lecture series, we invited the pianist Joonas Ahonen and the composer Bernhard Gander for a "2xHören" of Gander's piece "Peter Parker". In order to get an impression of the format, we recommend that you listen to the piece by scanning the QR-Code provided on this page, then read the interview with the composer and eventually listen to the piece a second time.

\section{Interview with Bernhard Gander}

Axel Petri-Preis (APP): Bernhard, your composition is called "Peter Parker". That's Spider-Man's civic alter-ego and a thoroughly unusual source of inspiration for a contemporary piano piece. How did this reference come about?

Bernhard Gander (BG): The first ideas for the piano piece came to me when I saw the film in the cinema. The unbelievably good 3D-shots of the flying scenes really stuck with me. It was very clear to me that I wanted to process these flying scenes, these dynamic 3D-scenes, into music. At the time, I thought that maybe the piano wasn't the best instrument for that. It would probably 
be better to represent this spatiality with a spatially distributed string quartet. But it was the restriction to the piano that eventually made the composition process interesting to me.

APP: You say you might have preferred a string quartet. One of your string quartets is inspired by the superhero Hulk. What predestines superheroes to serve as a source of inspiration for your music?

BG: In retrospect, I'm very glad that I wrote "Peter Parker" for piano, because Spider-Man himself is virtuosic and filigree, and that's better suited for the piano than for string instruments. Because with string instruments - when I think of the Hulk - I can blow up the physicality more. I have four string instruments, and I also associate the sonority more with that gross, pompous Hulk. So I'm glad about the choice of instrument. As for superheroes, musicians have always been superheroes to me. That's probably why they're such a good connecting point (laughs).

APP: "Peter Parker" is highly virtuosic and places the highest technical demands on the pianists. What is striking, however, is that you stick to a conventional way of playing the instrument, which you don't necessarily do in other pieces and with other instruments. What is behind this decision?

BG: With the piano, I'm only interested in the use of the keys. So the plucking in the piano or the percussion sounds on the piano don't interest me from a purely sonic point of view.

APP: In many of your piece titles and short introductory texts you refer to sources of inspiration outside of music. Do these references serve more for the process of composing or are they meant as a listening aid for the audience?

BG: It's both. For example, I could work musically in a purely abstract way. I could say I'm doing a theme with variations. "Peter Parker" would be that, too. I could also explain the piece that way. But because I was inspired by this story, I also make an inner script and work on it musically. Firstly, because it refreshes my musical workday and makes it more interesting, and I also think that listeners can discover quite a lot of correspondences when they listen, for example, when Spider-Man flies or crawls around on the ground. So when the audience hears a virtuoso passage, it's not just mere virtuosity on 
the instrument, there's a struggle going on. So that could also be an auditory aid.

APP: How important is it to you that the musicians who perform your pieces know about your thoughts on the piece?

BG: I'm almost more interested if they don't know anything about my background and approach the material purely musically, but I always leave that up to the musicians. If they ask me what I was thinking, I tell them. But I don't send them the instruction manual with the sheet music (laughs).

APP: You worked a lot with sketches at the beginning of the composition process for "Peter Parker". Can you please talk about how you went about that?

BG: I worked with graph paper in this piece, using mostly dots to represent individual notes and strokes to symbolize clusters. This way I get a good overview: do the individual elements occur very densely or rather loosely, do they make a distinctive rhythm? I can see on the sketch how it will sound. I can also improvise freely on it (sings).

APP: When you talk about improvising, do you also try things out on the piano while composing?

BG: No, mostly only on paper. I have a rough idea of the sound and make quick sketches. It's precisely in this quick writing that I get new results that I might not get with rigorous musing.

APP: Is the overall dramaturgy of the piece fixed from the beginning, or does it develop during improvisation while composing?

BG: I usually have the big dramaturgical arc in my head as an energy. So I know roughly how long the piece is going to be and I think about whether it's going to be divided into many parts or whether it's going to be one big rearing shape, for example. I determine something like that in my head fairly quickly and then start working it out in more detail.

APP: Let's come back to Spider-Man. How does this character flow into the music in concrete terms? 
Fig. 1: Sketch (extract) for Peter Parker

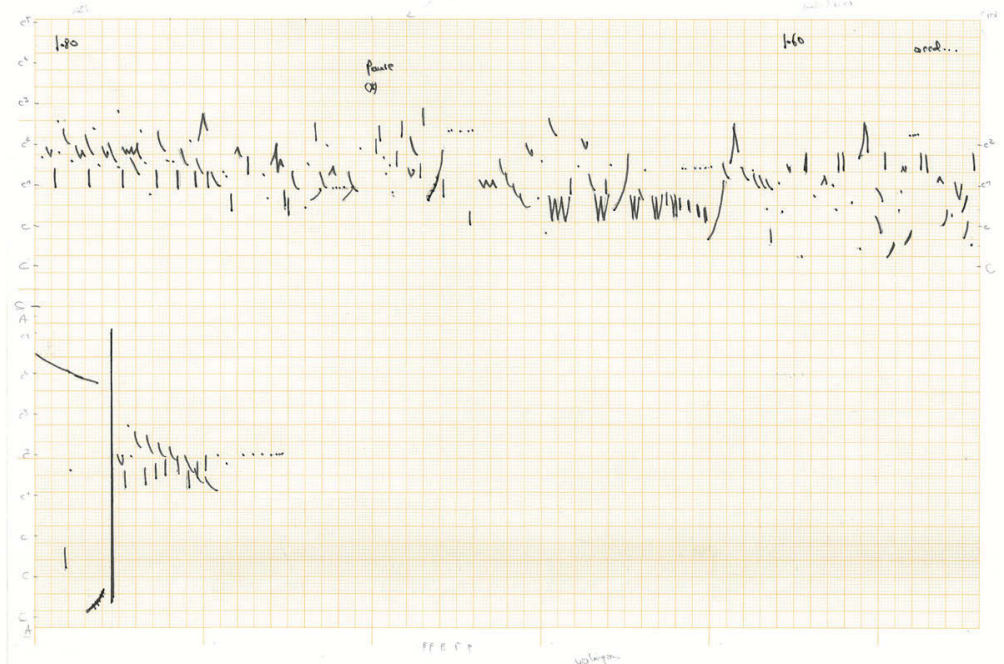

Source: private

BG: There are different scenes or adventures that Spider-Man has. In some scenes he just casts his web. At the very beginning, you hear a little bite where he gets infected by the spider. There are also fight scenes where he gets knocked to the ground, or he jumps in the air. Then, of course, there are these three-dimensional movements in space. The whole piece is like a comic book with different adventures.

APP: Comic book is a good keyword. You also used concrete images from Spider-Man comics as a template. Did you try to translate those images into music?

BG: Yes, they're actually 1:1 translations, because in comics, after all, bodies are depicted particularly well and clearly. When a body is tense, for example, you can see how the muscles stand out under the clothes, how the body is built up in a plastic and muscular way. I drew that for myself and then also tried to depict muscle progressions in short formal sections. 
APP: Do you have a favorite part of the piece?

BG: I think my favorite parts are the ones where he flutters through the New York skyscrapers really fast.

APP: If you were to give a listening tip to the listeners, what could they focus on in particular?

BG: The first time, you could really think of the character of Spider-Man based on the title. And the second time, just listen to what happens sonically. Like a Beethoven sonata.

\section{Bibliography}

Gander, Bernhard (2003): Peter Parker, Leipzig, London, New York: Edition Peters.

Musil, Monika (2013): Formate des Zwei- und Mehrfachhörens. Analytische Betrachtung des Musikvermittlungsformats “ 2 xören" der Körber-Stiftung, unpublished Master's Thesis (Anton Bruckner Privatuniversität Oberösterreich).

QR-code: Joonas Ahonen performing Bernhard Gander's "Peter Parker"; Source: YouTube [online: https://www.youtube.com/watch?v=oSxD6iNrx $\mathrm{wU}]$.

\section{Biographical notes}

Pianist Joonas Ahonen's musical interests take him from performing late $18^{\text {th }}$ century music on the fortepiano to giving premiere performances of the music of our times. He is a member of Klangforum Wien, one of the leading ensembles for contemporary music, and a member of the Rödberg fortepianotrio. Over the years, Ahonen has performed as a soloist with the Helsinki Philharmonic Orchestra, the Finnish Radio Symphony Orchestra, the BBC Symphony Orchestra and Ictus. His recordings on BIS label of Ligeti's Piano Concerto and Ives' Piano Sonata No. 2, "Concord" have received critical acclaim in the music press. https://www.joonasahonen.com 
Born in Lienz in 1969, Bernhard Gander studied piano and conducting at the Tyrolean Provincial Conservatoire and composition with Beat Furrer in Graz. He also studied at the Studio UPIC in Paris and at the Swiss Centre for Computer Music in Zurich. In 2004 he received the Musikförderungspreis of the City of Vienna, in 2006 the Erste Bank Composition Prize, in 2005 a government grant, and in 2012 the Ernst-Krenek Prize. He has also received commissions among others from Klangforum Wien, Ensemble Modern, RSO, Musikprotokoll, Wiener Konzerthaus, Donaueschinger Musiktage, Wiener Festwochen, Biennale Munich, Wittener Tage für neue Kammermusik. https://www.bernhardgander.at

Fig. 2: Joonas Ahonen, Bernhard Gander and Axel Petri-Preis in conversation at the lecture series, October 2019

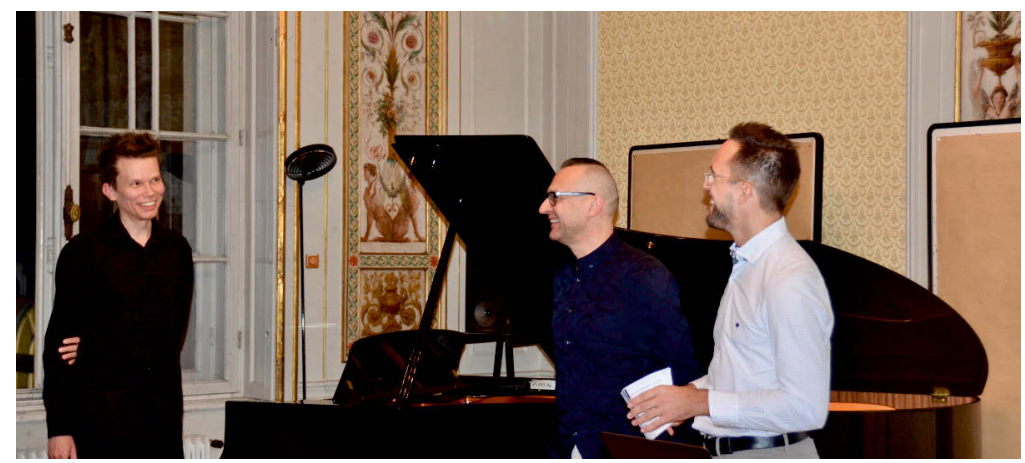

Source: private 
